\title{
Aluminum exposure in premature babies related to total parenteral nutrition and treatments
}

\author{
Emre Aşut ${ }^{1}$, Nilgün Köksal², Bayram Ali Dorum², Hilal Özkan² \\ ${ }^{2}$ Division of Neonatology, ${ }^{1}$ Department of Pediatrics, Uludağ University Faculty of Medicine, Bursa, Turkey. \\ E-mail: bayramalidorum@gmail.com
}

Received: 4th May 2017, Revised: 24th May 2017, 31st October 2017, Accepted: 2nd December 2017

SUMMARY: Aşut E, Köksal N, Dorum BA, Özkan H. Aluminum exposure in premature babies related to total parenteral nutrition and treatments. Turk J Pediatr 2018; 60: 385-391.

This study aimed to measure aluminum contamination of parenteral nutrition (PN) solutions and aluminum contents of parenteral products given to newborn infants for nutrition or treatment. In this study, the aluminum content of the first products used to prepare PN solutions for premature neonates, of the final parenteral products prepared therefrom, and of the parenteral drugs frequently used in newborn units was measured using the inductively coupled plasma mass spectrometry. The aluminum contamination of all parenteral nutritional products evaluated, except for one, was detected to be over the recommended doses. Of all the first products analyzed within the scope of the study, trace-element preparation, preparation containing fat-soluble vitamins, $20 \%$ dextrose solution, calcium gluconate ampoule and sodium phosphate ampoule indicated high aluminum contamination. The total aluminum content of the prepared final products was identified to be at least $40 \%$ higher than the total aluminum content of the ingredients added to the compound. Accordingly, the minimum amount of aluminum content was measured as $233 \mu \mathrm{g} / \mathrm{kg} /$ day in nutrition solutions prepared for a baby weighing $1,000 \mathrm{~g}$. Contamination was detected in 9 of the 18 drugs evaluated. This study indicated that the rate of aluminum exposure of the premature babies receiving parental nutrition is still much higher than the safe doses recommended as $5 \mu \mathrm{g} / \mathrm{kg} /$ day by the FDA. Products with lower aluminum content should be preferred in the care of premature infants.

Key words: aluminum, neurotoxicity, newborn, parenteral nutrition, prematurity.

Aluminum is the most abundant metal on Earth. Although aluminum does not have any biological role because of its insolubility at physiological $\mathrm{pH}$ values, high valency and slow distribution in in vivo environments may cause cytotoxic effects through protein aggregates as well as adverse effects on DNA protein. ${ }^{1}$

Premature infants with renal insufficiency receiving long-term parenteral nutrition $(\mathrm{PN})$ are at the risk of aluminum toxicity due to the bypass of the protective gastrointestinal mechanisms. In such babies, increased aluminum intake is an important risk factor for metabolic bone disease, anemia, cholestasis, and poor cognitive development. 2,3 Therefore, American Society for Parenteral and Enteral
Nutrition (ASPEN) states that the aluminum content of the PN solution prepared for preterm infants should be reduced. ${ }^{4}$ Moreover, the FDA recommends that daily intake of aluminum in infants should be $\leq 5 \mu \mathrm{g} / \mathrm{kg}$.

The aim of this study was to determine the concentration of aluminum in theoretically formulated samples of PN solutions, and aluminum contents of parenteral products given to newborn infants for nutrition or treatment. For this, we measured the aluminum content of PN solutions used in the neonatal intensive care unit and of each component added to the solutions and made a comparison between the expected and measured values. We also measured the aluminum content of 
Table I. Parenteral Nutrition Components and Measured Aluminum Concentrations.

\begin{tabular}{|c|c|c|c|c|}
\hline & Nutrition components evaluated & Content & Company & $\begin{array}{l}\text { Aluminum } \\
\text { concentration } \\
(\mathrm{mg} / \mathrm{L})\end{array}$ \\
\hline 1 & $5 \%$ Dextrose Solution & Dextrose in water & Osel & 1.42 \\
\hline 2 & 10\% Dextrose Solution & Dextrose in water & Polifarma & 0.45 \\
\hline 3 & 20\% Dextrose Solution & Dextrose in water & Polifarma & 2.35 \\
\hline 4 & $30 \%$ Dextrose Solution & Dextrose in water & Türk Tipsan & 1.68 \\
\hline 5 & $50 \%$ Dextrose Solution & Dextrose in water & Polifarma & ND \\
\hline 6 & Primene $10 \%$ & Amino acid solution & Baxter & 1.64 \\
\hline 7 & Smoflipid $20 \%$ & Lipid solution & Fresenius-Kabi & 2.20 \\
\hline 8 & Omegaven & Lipid solution & Fresenius-Kabi & ND \\
\hline 9 & Clinoleic $20 \%$ & Lipid solution & Baxter & 1.31 \\
\hline 10 & Calcium Picken 10\% (Ca-gluconate) & Calcium & Adeka & 3.35 \\
\hline 11 & Serum Sale $20 \%$ & $\mathrm{NaCl}$ & Galen & 2.09 \\
\hline 12 & Calcium Chloride 5,5\% & Calcium & Baxter & 0.93 \\
\hline 13 & Potassium Chloride 7.5\% & Potassium chloride & $\begin{array}{l}\text { İbrahim Ethem } \\
\text { Ulagay }\end{array}$ & 0.65 \\
\hline 14 & Potassium Chloride $22.5 \%$ & Potassium chloride & Osel & 0.54 \\
\hline 15 & Potassium Phosphates & Potassium phosphates & BBraun & 0.41 \\
\hline 16 & Magnesium Sulphate $15 \%$ & Magnesium sulphate & Onfarma & 0.39 \\
\hline 17 & Glycerophosphate & Sodium glycerophosphate & Fresenius-Kabi & 2.01 \\
\hline 18 & Soluvit N & Multivitamin & Fresenius-Kabi & 2.82 \\
\hline 19 & Vitalipid N Infant & Multivitamin & Fresenius-Kabi & 0.86 \\
\hline 20 & Cernevit (TM-12) & Multivitamin & Eczacıbaşı-Baxter & 7.26 \\
\hline 21 & Tracutil & Trace elements & Braun & 5.59 \\
\hline
\end{tabular}

ND: Not detected

the parenteral medications frequently used in neonatal intensive care units (NICUs) and noted the contamination level of the products, whose aluminum content was not specified on the label.

\section{Material and Methods \\ Study Design}

This prospective study was designed at the NICU of Uludağ University. The PN samples were prepared at Uludağ University Nutrition and Dietetics Unit. The study was conducted with the approval no. 2015-2278 dated 22 December 2015 of Uludağ University Faculty of Medicine Ethics Committee for Clinical Researches.

\section{Samples}

First, samples were taken from the 21 products listed in Table I that are used as the ingredients of the PN solutions prepared for newborn infants.

Second, samples were taken from three PN solutions that were prepared for patients whose weights were thought to be as $750 \mathrm{~g}, 1,000$ $\mathrm{g}$, and 1,250 g. PN solutions were prepared in the following volumes: glucose perfusion rate 8 $\mathrm{mg} / \mathrm{kg} / \mathrm{min}$; protein $3.5 \mathrm{~g} / \mathrm{kg} /$ day; lipid $3 \mathrm{~g} / \mathrm{kg} /$ day; sodium $4 \mathrm{mEq} / \mathrm{kg} /$ day, potassium $2 \mathrm{mEq} /$ $\mathrm{kg} /$ day; phosphorus $2 \mathrm{mmol} / \mathrm{kg} /$ day; calcium $2 \mathrm{ml} / \mathrm{kg} /$ day; magnesium $0.6 \mathrm{ml} / \mathrm{kg} /$ day; trace element solution (iron, zinc, manganesium, copper, chromium, selenium, molybdenum, iodine, fluorine) $1 \mathrm{ml} / \mathrm{kg} /$ day; water soluble vitamin solution (thiamine nitrate, riboflavine sodium phosphate, nicotinamide, pyridoxine hydrochloride, pantothenic acid, sodium ascorbate, biotin, folic acid, cyanocobalamin) 2 
Table II. The Content, the Amount of Aluminum in the Preparates Added to the Ingredients, and the Aluminum Amount Measured in the Final Products of Total Parenteral Nutrition Solutions Prepared as $130 \mathrm{ml} / \mathrm{kg} /$ day for Two Babies Weighing 750 grams (PNS-1) and 1,250 grams (PNS-2).

\begin{tabular}{|c|c|c|c|c|}
\hline & \multicolumn{2}{|c|}{ PNS-1 (EVA) } & \multicolumn{2}{|c|}{ PNS-2 (EVA) } \\
\hline & Volume (ml) & $\begin{array}{l}\text { Amount of } \\
\text { aluminum }(\mu \mathrm{g})\end{array}$ & Volume (ml) & $\begin{array}{l}\text { Amount of } \\
\text { aluminum }(\mu \mathrm{g})\end{array}$ \\
\hline Dextrose, $20 \%$ & 43.2 & 101.52 & 72 & 169.2 \\
\hline Primene, $10 \%$ & 30.0 & 49.2 & 50 & 82 \\
\hline Omegaven, $10 \%$ & 6.6 & $(-)$ & 11.5 & $(-)$ \\
\hline Clinoleic acid, $20 \%$ & 6.6 & 8.64 & 11.5 & 15.06 \\
\hline Serum Sale & 0.9 & 1.88 & 1.5 & 3.13 \\
\hline KPO4 & 1.5 & 0.61 & 2.5 & 1.02 \\
\hline Calcium gluconate, $10 \%$ & 1.5 & 5.02 & 2.5 & 8.3 \\
\hline Magnesium sulphate, $20 \%$ & 0.45 & 0.17 & 0.8 & 0.31 \\
\hline Tracutil & 0.75 & 4.19 & 1.2 & 7.26 \\
\hline Soluvit & 1.5 & 4.23 & 2.5 & 7.05 \\
\hline Vitalipid & 3.0 & 2.58 & 5 & 4.3 \\
\hline $\begin{array}{l}\text { Total estimated aluminum } \\
\text { amount }(\mu \mathrm{g})\end{array}$ & & 178.04 & & 297.63 \\
\hline $\begin{array}{l}\text { Total measured aluminum } \\
\text { amount }(\mu \mathrm{g})\end{array}$ & & 242.27 & & 563.85 \\
\hline
\end{tabular}

PNS: parenteral nutrition solution, EVA: in bags made from ethylene vinyl acetate

$\mathrm{ml} / \mathrm{kg} /$ day; fat soluble vitamin solution (vitamin A, vitamin D2, vitamin E, vitamin $\mathrm{K} 1$ ) $4 \mathrm{ml} /$ $\mathrm{kg} /$ day, and the total volume of the prepared solution was $130 \mathrm{ml} / \mathrm{kg} /$ day.

The PN solutions composed of $20 \%$ dextrose solution, Primene, Omegaven, ClinOleic, Serum Sale, Calcium Picken, Magnesium Sulfate, Tracutil, Soluvit, and Vitalipid were prepared for two infants weighing $750 \mathrm{~g}$ and 1250 (PNS-1 and PNS- 2) (Table II). For the baby weighing 1,000 g, however, 3 different PN solutions (PNS-3, 4, 5) were prepared using different potassium and phosphorus elements (Glycerophosphate, Calcium Picken, Potassium phosphate, Calcium chloride) by keeping other components the same. The solutions were prepared in bags made from ethylene-vinyl acetate (EVA) (PNS-3, 4, 5) (Table III).

Third, the parenteral medicines (Table IV) commonly used in neonatal intensive care units were prepared at the NICU drug preparation unit.

All samples were transferred to the laboratory at room temperature $\left(22^{\circ} \mathrm{C}\right)$, with no visible light. Before processing, the samples were prepared in smaller amounts ranging from minimum $1 \mathrm{ml}$ to maximum $5 \mathrm{ml}$.

\section{Methods and Devices}

All samples were subjected to microwave purification in the laboratory. Aluminum contents of the samples were measured using the inductively coupled plasma mass spectrometry (ICP-MS) method with an ELAN DRC II ICP-MS device (Perkin Elmer, Concord, Ontario, Canada) equipped with a dynamic reaction cell. The device was calibrated with the standard solution (Perkin Elmer, Concord, Ontario, Canada) provided by the manufacturer company (Perkin Elmer, Concord, Ontario, Canada). All solutions were prepared with purified water obtained from the Milli-Q Synthesis water purification system (Millipore, Tokyo, Japan). A commercial aluminum (Merck, Darmstadt, Germany) solution containing 1,000 mg aluminum was applied as the standard aluminum solution. Ultra-pure nitric acid was used for optimization.

\section{Laboratory Environment}

The measurements were carried out at the R\&D 
Table III. The Content, the Amount of Aluminum in the Preparates Added to the Ingredients, and the Aluminum Amount Measured in the Final Products of the TPN Solutions Prepared as $130 \mathrm{ml} / \mathrm{kg}$ day for a Baby Weighing 1,000 Grams.

\begin{tabular}{|c|c|c|c|c|c|}
\hline & Amount (ml) & $\begin{array}{c}\text { Amount of } \\
\text { Aluminum }(\mu \mathrm{g})\end{array}$ & $\begin{array}{l}\text { PNS-3 } \\
\text { (EVA) }\end{array}$ & PNS-4 (EVA) & PNS-5 (EVA) \\
\hline Dextrose, $20 \%$ & 57.6 & 135.36 & 135.36 & 135.36 & 135.36 \\
\hline Primene, $10 \%$ & 40 & 65.60 & 65.60 & 65.6 & 65.60 \\
\hline Omegaven ,10\% & 8.75 & $(-)$ & $(-)$ & $(-)$ & $(-)$ \\
\hline Clinoleic scid, $20 \%$ & 8.75 & 11.46 & 11.46 & 11.46 & 11.46 \\
\hline Serum Sale & 0.9 & 1.88 & 1.88 & 1.88 & 2.50 \\
\hline Potassium chloride, $7.5 \%$ & 2 & 1.30 & 1.30 & 1.30 & Negative \\
\hline Glycophos & 1.2 & 2.41 & 2.41 & 2.41 & Negative \\
\hline KPO4 & 2 & 0,82 & $(-)$ & $(-)$ & 0.82 \\
\hline $\mathrm{CaCl}$ & 1 & 0,93 & $(-)$ & 0.93 & 0.93 \\
\hline Calcium gluconate, $10 \%$ & 1 & 6.70 & 6.70 & $(-)$ & $(-)$ \\
\hline Magnesium sulphate, $20 \%$ & 0.6 & 0.23 & 0.23 & 0.23 & 0.23 \\
\hline Tracutil & 1 & 5.59 & 5.59 & 5.59 & 5.59 \\
\hline Soluvit & 2 & 5.64 & 5.64 & 5.64 & 5.64 \\
\hline Vitalipid & 4 & 3.44 & 3.44 & 3.44 & 3.44 \\
\hline $\begin{array}{l}\text { Total estimated aluminum } \\
\text { amount }(\mu \mathrm{g})\end{array}$ & & & 239.61 & 233.84 & 231.57 \\
\hline $\begin{array}{l}\text { Total measured aluminum } \\
\text { amount }(\mu \mathrm{g})\end{array}$ & & & 601.60 & 508.64 & 440.34 \\
\hline
\end{tabular}

PNS: parenteral nutrition solution, EVA: in bags made from ethylene vinyl acetate

Training and Measurement Center of Middle East Technical University, a laboratory accredited by the Turkish Accreditation Agency (TÜRKAK) in different fields according to TS EN ISO/IEC 17025: 2010 standard. Polypropylene pipettes washed with pure water were used to prevent contamination, and sample preparation was performed in a class 100 clean bench.

\section{Results}

In this study, the aluminum content was investigated for 45 samples. Of these 45 samples, 21 were from the ingredients added to the prepared PN solutions; 6 were from the ready-made PN solutions prepared for 3 infants in different weights, and 18 were taken from parenteral drugs commonly used in the NICUs.

Table I shows the name of the first products used as the ingredients of the PN solutions, the respective manufacturer, and the aluminum amount $(\mathrm{mg} / \mathrm{L})$ measured in the samples taken from the first products. No measurable aluminum content was detected in fish oilbased lipid emulsion and 50\% dextrose solutions. The highest aluminum content was found in lyophilized multivitamin preparation CernevitTM-12, trace element source Tracutil and Calcium Picken preparation- $7.26 \mathrm{mg} / \mathrm{L}$, $5.59 \mathrm{mg} / \mathrm{L}$ and $3.35 \mathrm{mg} / \mathrm{L}$, respectively (Table I).

While the total amount of aluminum contained in the ingredients of the PN solution (PNS-1) prepared for the infant weighing $750 \mathrm{~g}$ was $178 \mu \mathrm{g}$, the amount of aluminum in the final product prepared in EVA was measured 242 $\mu \mathrm{g}$ (Table II). Accordingly, the daily aluminum intake with PN was calculated as $322 \mu \mathrm{g} / \mathrm{kg}$.

Whereas the total amount of aluminum contained in the ingredients of the PN solution (PNS-2) prepared for the infant weighing $1,250 \mathrm{~g}$ was $297 \mu \mathrm{g}$, the amount of aluminum measured in the final product prepared in EVA was $563 \mu \mathrm{g}$ (Table II). Therefore, the daily amount of aluminum intake through PN was calculated as $450 \mu \mathrm{g} / \mathrm{kg}$.

Furthermore, the total amount of aluminum contained in the ingredients of the PN solution (PNS-3) prepared for the infant weighing 1,000 
g using $\mathrm{KCl}$ for potassium, glycerophosphate for phosphorus and Calcium Picken for calcium was $239 \mu \mathrm{g}$, whereas the aluminum content in the final product prepared in EVA was measured $602 \mu \mathrm{g}$ (Table III).

On the other hand, the total amount of aluminum contained in the ingredients of the PN solution (PNS-4) prepared for an infant weighing $1,000 \mathrm{~g}$ using $\mathrm{KCl}$ for potassium, glycerophosphate for phosphorus and Calcium $\mathrm{Cl}$ was $233 \mu \mathrm{g}$ and the aluminum content of the final product prepared in EVA, was found $508 \mu \mathrm{g}$ (Table IV).

Moreover, the total amount of aluminum contained in the ingredients of the PN solution (PNS-5) prepared for an infant weighing 1000 $\mathrm{g}$ using potassium phosphate for potassium and phosphorus and calcium chloride for calcium was measured $231 \mu \mathrm{g}$ while the aluminum contained in the final product was found 440 $\mu \mathrm{g}$ (Table III).

We also analyzed the aluminum content of
18 parenteral drugs administered for newborn patients (Table IV). In 9 of 18 drugs, the amount of aluminum content was nonmeasurable. Nevertheless, there was high amount of aluminum in classical amphotericin B preparation and caffeine citrate preparation that were $5.67 \mu \mathrm{g} / \mathrm{ml}$ and $5.59 \mu \mathrm{g} / \mathrm{ml}$, respectively. Aluminum content of the other drugs is shown in Table IV.

\section{Discussion}

Aluminum makes up approximately $8 \%$ of the Earth's crust. Although no disease associated with the insufficiency of this element, which is abundant in our environment, has been reported to date, aluminum toxicity continues to be a major problem.5 Dangerous effects of aluminum toxicity in premature babies have been known for nearly 30 years. Bishop et al. ${ }^{6}$, for the first time, drew attention to this matter with a report on a premature baby who died of aluminum intoxication in 1989. Since then, researchers have taken measures to minimize aluminum toxicity. After this first report, Bishop

Table IV. Measured Aluminum Concentrations of Parenteral Drugs.

\begin{tabular}{|c|c|c|c|}
\hline & $\begin{array}{l}\text { Drugs and their } \\
\text { trading names }\end{array}$ & Company & $\begin{array}{l}\text { Aluminum } \\
\text { concentration ( } \mu \mathrm{g} / \\
\mathrm{ml})\end{array}$ \\
\hline 1 & Ampicillin (Ampisid 500 mg) & İbrahin Ethem Ulagay & 1.83 \\
\hline 2 & Gentamicin (Genta 80 mg) & İbrahin Ethem Ulagay & 1.79 \\
\hline 3 & Cefotaxime (Eqitax 0.5 gr) & Tüm Ekip & $(-)$ \\
\hline 4 & Amikacin (Amijeksin 100 mg) & Tüm Ekip & 1.70 \\
\hline 5 & Cefepim (Ekipim 500 mg) & Tüm Ekip & 0.38 \\
\hline 6 & Meropenem (Merosid 500 mg) & Koçak Farma & $(-)$ \\
\hline 7 & Vancomycin (Vancotek 500 mg) & Koçak Farma & $(-)$ \\
\hline 8 & Colistin (Colimycin 150 mg) & Koçak Farma & $(-)$ \\
\hline 9 & Linezolid (Zizolid 2 mg) & Biofarma & $(-)$ \\
\hline 10 & Ciprofloxacin (Ciflosin $2 \mathrm{mg} / \mathrm{ml}$ ) & Deva & $(-)$ \\
\hline 11 & Fluconazole (Candisept 100 mg) & Vem & $(-)$ \\
\hline 12 & Classical amphotericin B (Fungizone 50 mg) & Bristol Myers Squibb & 5.67 \\
\hline 13 & $\begin{array}{l}\text { Liposomal amphotericin B (Ambisome } 50 \mathrm{mg} / \\
12 \mathrm{ml} \text { ) }\end{array}$ & Gilead Sciences & 0.13 \\
\hline 14 & Caspofungin (Cancidas $50 \mathrm{mg} / 10 \mathrm{ml}$ ) & Merck Sharp Dohme & $(-)$ \\
\hline 15 & Caffeine citrate (Kafesit 60 mg/3 ml) & Berko & 5.59 \\
\hline 16 & Pentoxifylline (Vasoplan 100 mg/5 mL) & Mustafa Nevzat & $(-)$ \\
\hline 17 & Furosemide (Furomide 20 mg/2 ml) & Deva & 0.58 \\
\hline 18 & Vitamin $\mathrm{K}$ (Konakion $2 \mathrm{mg} / 0.2 \mathrm{ml}$ ) & Roche & 3.54 \\
\hline
\end{tabular}


et al. ${ }^{3}$ examined a total of 277 premature babies receiving a standard $\mathrm{PN}$ solution or a low-aluminum-content PN solution. In that study, the infants given a PN solution with high aluminum content had lower scores on the Bayley Mental Developmental Index performed at the 18th month. In the light of the analyses, Bishop et al. ${ }^{3}$ speculated that infants receiving high-aluminum-content $\mathrm{PN}$ would lose 1 point per day on the Bayley Mental Development Index. In the following year, Stockhausen et al. ${ }^{7}$ reported that morbidities such as BPD, NEC, cholestasis and osteopenia are more prevalent among the premature infants receiving high aluminum content.

Fewtrell et al. ${ }^{8}$ have investigated later bone health of the preterm infants, who were examined by Bishop et al. ${ }^{3}$ earlier, after 15 years of follow-up. That study reporting the results obtained from the examinations of 59 adolescents indicated that neonates who were exposed to parenteral aluminum would have significantly lower hip bone mineral content during adolescence. Fewtrell et al. ${ }^{8}$ indicated that the adverse consequences of early aluminum exposure may continue in the long term.

After the publication of the aforementioned studies, the FDA published a report recommending aluminum intake to be limited to $5 \mu \mathrm{g} / \mathrm{kg} /$ day and made it obligatory to express the aluminum content of large volume parenteral products on label as follows: "Contains no more than $25 \mu \mathrm{g} / \mathrm{L}$ of aluminum". The aluminum content of small volume parenteral products must be stated on the label. ${ }^{9}$ However, Poole et al. ${ }^{10}$ argued that this suggestion can be applicable only for the individuals over $50 \mathrm{~kg}$ in weight.

In the present study, we observed that the aluminum contents of the PN solutions prepared with the products, which are widely used in our country, are much higher than the recommended levels. According to the American Society for Clinical Nutrition and ASPEN, daily aluminum intake of $60 \mu \mathrm{g} / \mathrm{kg}$ causes toxicity. ${ }^{11}$ However, in our study, the lowest aluminum content, which an infant weighing $1,000 \mathrm{~g}$ was exposed to through daily PN intake, was $366 \mu \mathrm{g} / \mathrm{kg}$ and it is much greater than the toxic dose.

Calcium and phosphate salts are reported as the most important aluminum sources in PN solutions in the literature. Huston et al. ${ }^{12}$ have compared $\mathrm{CaCl} 2$ and $\mathrm{Ca}$-gluconate preparations and indicated that $\mathrm{Ca}$-gluconate should not be preferred because of its high aluminum content. Also, there are studies indicating that trace elements and vitamin solutions have high aluminum content. ${ }^{2}$ In accordance with all these reports, we identified trace elements (Tracutil) and multivitamin preparations (Cernevit) to be significant aluminum resources besides calcium and phosphate salts.

In another study conducted by Poole et al. ${ }^{10}$, the total amount of aluminum contained in the products used to prepare the PN solutions was measured, and a comparison was made between the total aluminum content of ingredients and the total aluminum content of the final products. As a result, the amount of aluminum in the final product was found to be higher. Similarly, we found that the aluminum content of the PN solution prepared as the final product was at least $50 \%$ higher than the total aluminum content of the ingredients.

De Oliveira et al. ${ }^{13}$ investigated the difference between the aluminum contaminations of the first commercial products and the final PN solutions by measuring the aluminum content at different phases of PN preparation. Ultimately, De Oliveira et al. ${ }^{13}$ indicated that during the preparation and administration phases, the aluminum contents of the products increases by nearly 40 percent and associated that with the materials applied.

In this study, we also measured the aluminum contents of parenteral drugs, which are frequently used in the newborn units. Aluminum contamination was found to be $>1 \mu \mathrm{g} / \mathrm{ml}$ in ampicillin, gentamycin, amikacin, caffeine citrate, classical amphotericin and vitamin $\mathrm{K}$ preparations. Caffeine citrate, which is routinely used particularly for premature infants weighing below $1250 \mathrm{~g}$, make a substantial contribution to aluminum exposure due to its high aluminum content.

Randomized-controlled studies in the literature and the adjustments made accordingly have enabled significant reduction in aluminum exposure of premature babies in developed countries. ${ }^{10}$ 
In this study, the ICP-MS technique was used to analyze the aluminum content of the samples since ICP-MS is a powerful technique for measuring aluminum levels in biological materials. ${ }^{14}$ We did not measure the aluminum amount contained in the patients' serums. This can be considered as a limitation of our study.

Preterm infants who are fed or treated with parenteral nutrition are faced with the risk of aluminum toxicity. This risk becomes even more serious especially in developing countries, where there are no regulations limiting the aluminum content of products. Aluminum content of all products preferred for parenteral nutrition in premature infants should be measured and expressed on product labels. Products with lower aluminum content should be preferred in the treatment of premature infants.

The daily amounts of aluminum received by premature babies from parenteral nutrition solutions should be calculated and tried to be kept below the FDA's recommended limit of $5 \mu \mathrm{g} / \mathrm{kg} /$ day.

\section{Acknowledgement}

This project was supported by Scientific Research Projects Unit of Bursa Uludag University (Number: KUAP(T)-2016/2).

\section{REFERENCES}

1. Lukiw WJ. Evidence supporting a biological role for aluminum in chromatin compaction and epigenetics. J Inorg Biochem 2010; 104: 1010-1012.

2. Fanni D, Ambu R, Gerosa C, et al. Aluminum exposure and toxicity in neonates: A practical guide to halt aluminum overload in the prenatal and perinatal periods. World J Pediatr 2014; 10: 101-107.

3. Bishop NJ, Morley R, Chir B, Day P, Lucas A. Aluminum neurotoxicity in preterm infants receiving intravenousfeeding solutions. N Engl J Med 1997; 336: 1557-1561.

4. Nehra D, Carlson SJ, Fallon EM, et al. A.S.P.E.N. Clinical Guidelines: Nutrition support of neonatal patients at risk for metabolic bone disease. J Parenter Enter Nutr 2013; 37: 570-598.

5. Smith BS, Kothari H, Hayes BD, et al. Effect of additive selection on calculated aluminum content of parenteral nutrient solutions. Am J Health Syst Pharm 2007; 64: 730-739.
6. Bishop NJ, Robinson MJ, Lendon M, Hewitt CD, Day JP, O'hara M. Increased concentration of aluminium in the brain of a parenterally fed preterm infant. Arch Dis Child 1989; 64: 1316-1317.

7. von Stockhausen HB, Schrod L, Brätter P, Rösick U. Aluminium loading in premature infants during intensive care as related to clinical aspects. J Trace Elem Electrolytes Health Dis 1990; 4: 209-213.

8. Fewtrell MS, Bishop NJ, Edmonds CJ, Isaacs EB, Lucas A. Aluminum exposure from parenteral nutrition in preterm infants: Bone health at 15-year follow-up. Pediatrics 2009; 124: 1372-1379.

9. Food and Drug Administration. Aluminum in larger and small volume parenterals used in total parenteral nutrition; amendment; delay of effective date. Fed Reg 2002; 67: 70691-70692.

10. Poole RL, Pieroni KP, Gaskari S, Dixon T, Kerner JA. Aluminum exposure in neonatal patients using the least contaminated parenteral nutrition solution products. Nutrients 2012; 4: 1566-1574.

11. Klein GL, Alfrey AC, Shike M, Sherrard DJ. Parenteral drug products containing aluminum as an ingredient or a contaminant: Response to FDA notice of intent. Am J Clin Nutr 1991; 53: 399-402.

12. Huston RK, Heisel CF, Vermillion BR, Christensen JM, Minc L. Aluminum content of neonatal parenteral nutrition solutions: Options for reducing aluminum exposure. Nutr Clin Pract 2017; 32: 266-270.

13. de Oliveira SR, Bohrer D, Garcia SC, do Nascimento PC, Noremberg S. Aluminum content in intravenous solutions for administration to neonates: Role of product preparation and administration methods. J Parenter Enteral Nutr 2010; 34: 322-328.

14. Keith S, Jones D, Rosemond Z, Ingerman L, Chappell L. Toxicological Profile for Aluminum. 2008. Available from: https://www.atsdr.cdc.gov/toxprofiles/tp22.pdf Accessed on 11.08.2017. 